\title{
FARINHA DE FEIRA: MEMÓRIAS E IDENTIDADES DE VENDEDORES EM FEIRAS DO BAIRRO DO GUAMÁ, BELÉM(PA)
}

\author{
Flavio Henrique Souza Lobato ${ }^{1}$ \\ Voyner Ravena-Cañete ${ }^{2}$
}

\section{Introdução ${ }^{3}$}

James George Frazer discorria sobre como as essências culturais da humanidade estariam sendo perdidas e as memórias morrendo juntamente com as gerações mais antigas. Em virtude disso, o autor implorou aos novos pesquisadores que realizassem expedições, preocupado em documentar uma grande parcela da "inestimável evidência da história do homem antes que seja tarde demais. Pois, muito logo, as oportunidades que ainda temos terão desaparecido" (Frazer, 2005: 124).

Passado mais de um século, a história indica que o autor estava certo, visto que, na conjuntura atual, as sociedades têm sofrido processos de mudanças profundas que alteram as dinâmicas sociais subitamente. Nas grandes cidades, já não é possível identificar com facilidade peculiaridades e autenticidades culturais, tudo parece estar “igual”, e poucos são os lugares que ainda possuem força para resistir à pressão modeladora da globalização e da indústria cultural.

Nesse cenário, merecem destaque as feiras por serem locais que carregam trajetórias, relíquias do passado, singularidades, crenças, tradições, costumes e identidades de um grupo. Constituem-se como espaços onde ainda é possível respirar, sentir, tocar e ver o "coração" de uma cultura, por esse motivo, as feiras são paradas obrigatórias daqueles que almejam conhecer a tradição de determinada cidade.

As feiras, no contexto da cidade de Belém do Pará, em especial aquelas que se formaram nas proximidades do Rio Guamá, por onde navega grande parte dos alimentos que abastecem a cidade, apresentam fortes (inter)relações com a cultura cabocloribeirinha, a base da cultura amazônida. Para além das relações comerciais, os pequenos barcos que ancoram nos trapiches dos portos ou os caminhões que estacionam nas feiras, carregam em suas "bagagens" práticas culturais intrínsecas à cultura paraense,

\footnotetext{
${ }^{1}$ Universidade Federal do Pará, Brasil.

${ }^{2}$ Universidade Federal do Pará, Brasil.

${ }^{3}$ Este artigo vincula-se ao Projeto de pesquisa Mercados interculturais: linguagens, práticas e identidades em contextos amazônicos, financiado pelo Edital Universal-CNPq/2013 e coordenado pela $\operatorname{Prof}^{\mathrm{a}} \operatorname{Dr}^{\mathrm{a}}$ Carmem Izabel Rodrigues - PPGSA/UFPA.
} 
por isso os residentes da cidade conferem às feiras do bairro do Guamá significativa importância.

Contudo, esses espaços têm sofrido fortes interferências de processos que se desenham sobre várias feições, principalmente ambientais/espaciais, sociais, políticos e econômico-culturais. A farinha, elemento importante na culinária paraense, destaca-se nesse panorama em virtude do aumento de preço, que desencadeiam significativas alterações nas práticas de comercialização, consumo, e também mudanças na memória e na identidade do paraense "papa-chibé"4.

Diante da possibilidade de perda no que se refere aos aspectos culturais, como os saberes, os fazeres, as memórias e as identidades envoltas às práticas culturais ligadas à farinha, é que se fundamenta este estudo. Tem-se como objetivo investigar a memória e os processos identitários, que vendedores de farinha em portos/feiras do bairro do Guamá, na cidade de Belém, apresentam sobre os processos de produção, comercialização e consumo desse produto.

Este trabalho não objetiva investigar "o passado através da memória, mas de procurar compreender o presente a partir das reconstruções que são feitas [pelos feirantes] do passado" (Santos, 2003: 275). E, a partir da compreensão de que o presente de hoje será o passado do amanhã, este estudo, pretende contribuir com a compreensão, também, do amanhã.

Para tanto, o caminho metodológico percorrido partiu de uma abordagem qualitativa, com pesquisas bibliográficas, documentais e de campo, por meio de uma aproximação etnográfica ao utilizar técnicas de pesquisas que perpassaram por observações sistemáticas, registros fotográficos, conversas informais, aplicação de formulários e de entrevistas.

Deste modo, pôde-se construir um referencial teórico concernente à memória, à identidade, às feiras, delimitando e contextualizando o histórico desses espaços em Belém, lócus e objeto de estudo desta pesquisa. Ao coletar dados de grande relevância para o alcance dos objetivos propostos, contribui-se para o avanço nos estudos de temas das quais trata este trabalho.

Como resultados, puderam ser obtidos dados que revelaram como se estabelece a venda do produto, a memória de vendedores de farinha sobre os processos de produção, 
comercialização e consumo, assim como, a importância do produto para os vendedores e consumidores. Os resultados também evidenciam os possíveis fatores de encarecimento da farinha e seus desdobramentos, as manifestações e reflexões do consumidor paraense acerca do aumento de preço do produto e as consequências desse processo na identidade "papa-chibé".

Este estudo problematiza, assim, as formas de produção, comercialização e consumo da farinha, a partir das memórias, das trajetórias e identidades de feirantes do bairro do Guamá, em especial após o evento da alta de preço da farinha vivida nos últimos anos nos portos, mercados e feiras de Belém do Pará.

\section{Feiras: lugares de memória, lugares de identidade(s)}

O termo feira é de origem latina, feria, que significa "dia de festa" (Leitão, 2010). Por esse motivo, Santos e Rodrigues (2013) discorrem que grande parte dos estudiosos, que possuem como objeto de estudo as feiras, fazem menção a reuniões que aconteciam na Idade Média entre mercadores, que no embalo de festas e festejos religiosos comercializam ou trocavam inúmeros produtos. No entanto, Pirenne (1936 apud Sato, 2007) defende que as feiras iniciaram-se ainda no século IX na Europa e foram responsáveis pelo abastecimento local.

Ao fazer comparações com o atual cenário, nota-se que esse abastecimento ainda se configura como fator preponderante para o surgimento e consolidação de feiras. As feiras, apesar de surgirem com motivações semelhantes de acordo com Luiz Mott (2000), apresentam lógicas próprias e específicas, caracterizando-se como locais de comercialização/negociação de uma grande variedade de produtos a preços acessíveis. Sendo os locais onde geralmente a população mais carente detém a possibilidade de melhor abastecer a dispensa, comprando um maior número de mantimentos com pouco recurso financeiro.

No entanto, Freitas (2006) ressalta que mais do que práticas de comercialização de verduras, legumes, frutas, carnes, dentre outros produtos alimentícios, as feiras funcionam como palcos de produção, reprodução, (re) afirmação e exposição das práticas culturais de um determinado grupo. Afinal, muito do que é comercializado

\footnotetext{
${ }^{4}$ Papa-chibé é uma autodefinição entre os paraenses, em especial, àqueles que são apreciadores do Chibé. O Chibé é uma mistura de água com farinha de mandioca, alguns acrescentam outros ingredientes na mistura, como o sal, por exemplo.
} 
nesses espaços é fruto, na totalidade ou em parte, de práticas artesanais que corriqueiramente são carregadas de vasta riqueza de detalhes, simbologias e complexidades, expondo os mais singulares e, ao mesmo tempo, mais notórios aspectos culturais que representam uma coletividade.

Nas feiras/mercados, segundo Nascimento e Rodrigues (2011: 165), entende-se "como parte dessa prática cultural os saberes" e fazeres, que na realidade são produtos das vivências e memórias de um grupo, no qual se expressam sob o modo das dinâmicas cotidianas, - arrumação das barracas e mercadorias, as formas de persuadir os clientes, etc. - e que seguem a lógica de transmissão de conhecimentos às novas gerações, que têm e exercem um papel importante na construção do sentimento de pertencimento e identidade(s) do grupo. São espaços, também, de informações do que aconteceu e do que está acontecendo, trazendo "resquícios de um passado" e sendo "um local de ouvir e contar estórias, um local de sociabilidade" (Freitas, 2006: 22). E, portanto, são locais de (re) criações e disseminações dos aspectos constituintes de uma cultura.

Dessa forma, as feiras e mercados configuram-se como verdadeiras tertúlias de vários traços componentes da cultura de um grupo, estando dispostos por seus espaços "valores, crenças, costumes, hábitos e fatores históricos materiais e imateriais que permeiam, de forma dinâmica, os modos de vida social" (Carneiro; Oliveira; Carvalho, 2010: 7; Laraia, 1997).

Logo, é possível visualizar, nesses locais, de maneira bem mais expressiva e "pura", as trajetórias e memórias, por conseguinte, a identidade de um grupo, que em outros espaços, como é o caso das áreas centrais das cidades, não é possível visualizar com a mesma intensidade, devido às inovadoras dinâmicas impostas pelos processos de modernização da sociedade, tendo como exemplo categórico a globalização. Por este motivo, muitos turistas passam a conhecer e compreender melhor a cultura e a identidade da região visitada, se encantando, sentindo, respirando e degustando as cores, os cheiros e os sabores "puros" do até então desconhecido.

Essa percepção é possível pelo fato das feiras serem espaços onde a lógica célere da ruralidade/simplicidade/autenticidade ainda se manifesta com grande fervor. As trajetórias dos feirantes, por exemplo, formadas a partir do adquirir/incorporar conhecimentos e experiências vivenciadas até o presente, constituem-se a base da vivência pessoal, projetando-se e materializando-se no espaço sob a forma de tradições, manifestações e demais práticas culturais. 
As memórias assumem um papel essencial, uma vez que estas acabam por "fornecer dados importantes sobre contextos, processos e conflitos sociais que fazem parte da vida" de determinado grupo (Santos, 2003: 271). Assim, as memórias funcionam como um fio condutor de processos culturais construídos ao longo do tempo, por intermédio do rememorar, das lembranças, que o tudo e o todo ali apresentados, têm/fazem sentido. Sob este prisma, Santos (2003: 273-274) pontua que:

\begin{abstract}
Podemos compreender a memória como sendo qualquer forma de pensamento, percepção ou prática que tenha o passado como sua principal referência. A memória de experiências passadas está presente em cada palavra que dizemos, em cada passo que damos ou em cada sonho que construímos. Ela está presente no pensamento, nos sentimentos e percepções, bem como na imaginação. Tudo o que sabemos ou que podemos aprender se deve às memórias que possuímos ou que iremos adquirir.
\end{abstract}

Nesta perspectiva, Wehling e Wehling (2003) e Michel Pollak (1992) ao trabalharem a concepção de memória, reiteram que esta é um meio pelo o qual são reproduzidas as marcas e simbologias de uma cultura através de suas manifestações. Os autores ponderam ainda que a memória é um componente de suma importância na constituição e afirmação da identidade, bem como na própria cidadania, haja vista que é um parâmetro de definição daquilo que é comum a um coletivo e o que o difere dos demais. Isto é, a memória, estabelece e ratifica os sentidos de pertença e de "demarcações" de uma cultura, tendo a memória e identidade (inter)relações e influências mútuas (Silva, 2012: 782).

No que se refere à identidade, Silva (2012: 782) afirma que a identidade cultural é como pilar de sustentação e como legado das sociedades, "onde o passado e seu histórico são símbolos valorizados no cotidiano e se preservam através de suas experiências ao longo das gerações”. Dessa maneira, as feiras são os locais que apresentam e representam, em muitos casos, a identidade de um povo.

No entanto, na pós-modernidade, Stuart Hall (1992: 7) discorre que "as velhas identidades, que por tanto tempo estabilizaram o mundo social, estão em declínio, fazendo surgir novas identidades e fragmentando o indivíduo moderno, até aqui visto como um sujeito unificado". Assim, a identidade cultural se apresenta de forma tão fragmentada que o ser humano passa a apresentar inúmeras identidades, e não mais uma. As identidades/identificações são tantas que o ser humano se vê em uma "crise identitária". 


\section{As feiras em Belém (PA): O Bairro do Guamá, seus portos e feiras}

A composição das feiras da capital paraense Belém se apresenta bastante diferenciada de outras regiões do País. Aspectos como constituição histórica, localização geralmente às margens dos rios, funcionalidade, formas de uso e ocupação espacial conferem às feiras da cidade verdadeiros recortes das diversas produções socioespaciais (Medeiros, 2009), autênticas e representativas da cultura paraense caboclo-ribeirinha.

A gênese das feiras em Belém, segundo Medeiros (2009), justifica-se na necessidade de abastecer o contingente populacional, em especial os que possuíam poucos recursos. O contexto de exploração da borracha - Belle Époque - aliado ao processo de crescimento horizontal da cidade, ocasionado principalmente pelo processo migratório, concebeu a cidade novas configurações na dinâmica socioespacial, onde as novas áreas, mais distantes dos centros, se encontravam, de certa maneira, restritas (Lobato; Aires; Ravena-Cañete, 2013).

Essas novas configurações, de certa forma, também desencadearam, conforme pontua Medeiros (2009: 3), "o alargamento das relações de trocas para outros locais da cidade", tendo em vista que as autoridades da época tinham grande preocupação com o abastecimento e qualidade dos produtos oferecidos à toda a população.

Medeiros (2009) assinala que as feiras, primeiramente formaram-se próximas às margens dos rios, pelos quais se estabeleciam (estabelecem-se) transações comercias (e socioculturais) entre às ruralidades dos interiores amazônicos e a cidade grande. Estes primeiros são locais, em geral as ilhas, - onde residem as populações tradicionais - que apesar da separação do rio, possuem uma relação estreita e direta com a população de Belém, tendo em vista que grande parte dos gêneros alimentícios, cosumidos pelos citadinos, é retirada e/ou produzida no interior dessas regiões e transportados em pequenas embarcações para serem comercializados na cidade.

Em outro panorama, as feiras surgem em vias públicas da cidade, motivadas pela formação e consolidação de vários mercados particulares pela cidade. O surgimento desses mercados se concebeu dada a preocupação com o abastecimento do município, que vinha crescendo de forma desordenada. Como foi o caso, no século $\mathrm{XX}$, do Intendente de Belém, Antônio Lemos, que passou a incentivar a construção de pequenos 
mercados, pois acreditava que funcionavam como meios de ofertar alimentos, principalmente os regionais, aos locais onde se encontravam as camadas populares menos favorecidas (Medeiros, 2009). Tal fato se evidencia por meio deste pequeno trecho de um de seus relatórios administrativo da cidade:

[...] tenho afirmado nestes volumes a minha opinião de que os grandes Mercados não devem excluir os pequenos e de que, quanto maior for [sic] o número destes disseminados pela cidade e pelos subúrbios, sobretudo nos pontos mais afastados, melhor servida será a população, com a especificidade a população pobre. Assim pensando, não me poupo em continuar a encorajar os proprietários desses pequenos mercados, hoje felizmente em número apreciável.

[...] Constantemente abastecidos de excelletes generos [sic], de primeira qualidade, esses úteis estabelecimentos conservam, todavia, os preços correntes dos seus congêneres que negociam em grande escala, oferecendo desse modo todas as facilidades aos consumidores. (Lemos, 1908 apud Medeiros, 2009: 5)

Os incentivos de Antônio Lemos e o crescimento da malha urbana, atrelados à procura por parte da sociedade belenense pelos inúmeros produtos comercializados nesses espaços, conforme os apontamentos de Medeiros (2009), conferiram aos mercados, com o passar dos anos, grande destaque. Tal fato propiciou a rápida formação, expansão e consolidação de feiras livres em vias públicas, aos arredores desses mercados e por toda a cidade. Este crescimento pode ser interpretado também pelo fato de que esses espaços, de certa maneira, configuraram-se como oportunidades de emprego e geração de renda para pessoas menos favorecidas.

Desde então, a cidade de Belém, de acordo com dados do Anuário Estatístico do Munícipio de Belém (2010), passou a possui 42 (quarenta e duas) feiras, dentre estas, 4 (quatro) não são legalizadas, estando algumas dispostas nas proximidades ou nas margens do Rio Guamá ou Baía do Guajará.

Medeiros (2009: 6) destaca que dependendo da disposição das feiras pela cidade, as lógicas de funcionalidade destas acabam por se divergir. As feiras que se encontram, por exemplo, "próximas à margem do rio compartilham processos e estratégias socioespaciais assimétricas em relação às feiras dispostas às vias públicas da cidade".

Nessa concepção, o bairro do Guamá, lócus desta pesquisa, merece destaque, uma vez que é considerado o mais populoso da cidade, com um total de 94,610 mil habitantes (Instituto, 2010), sendo que o bairro possui este nome por causa da referência a sua localização às margens do Rio Guamá. Seus limites compreendem uma área em formato parecido com um polígono, que é envolvido pela margem direita do Rio Guamá, os bairros da Condor, Cremação Terra Firme e Jurunas. 
Sua formação se deu por vários fatores, Cruzinha (2003) desta que um dos fatores, certamente, se deve pela construção de vários empreendimentos públicos, como a Colônia de Hansenianos, que funcionava como um meio de separar as pessoas doentes do restante da população. De acordo com a autora, as autoridades da época, argumentavam que tal doença era contagiosa. As pessoas eram arrancadas de suas casas e levadas à colônia, o que levou muitos dos parentes de pessoas infectadas a morar próximo desse lugar. Mais tarde outros espaços públicos foram construídos ali, incentivando mais ainda o crescimento da população e, por conseguinte, do bairro.

Por outro lado, a localização privilegiada às proximidades do rio foi determinante para que esse espaço de habitação tivesse um crescimento significativo, cuja ocupação configurou-se pela apropriação indevida das denominadas áreas de marinha. Tal apropriação se deu tanto por agentes econômicos privados da sociedade local, como por segmentos de moradores de origem rural que se alocaram nessa área (Cruzinha, 2003), incitando a formação de portos pelo bairro.

Estes funcionaram (e funcionam) como portais de ligação, por onde uma grande parcela dos gêneros alimentícios que ajudavam (e ainda ajudam) a abastecer a cidade, chegavam (chegam). Sendo em si mesmos, espaços de mudança e do imponderável, através de sua dinâmica célere e sua capacidade de aglutinar agentes sociais, mercadorias, práticas e saberes. De tal modo, que ao longo dos anos se estabeleceu a formação de inúmeras feiras pelo bairro, tendo a finalidade de fornecer à população, através da comercialização, os produtos recém-chegados do interior do Estado, o que fomentou mais ainda o acréscimo de relações perfiladas por uma lógica rural e urbana. Tal processo desempenhou um papel expressivo na economia da cidade e na geração de empregos para muitas famílias do bairro e de toda a cidade de Belém.

Dentre os produtos dispostos à venda em portos, mercados e feiras do bairro do Guamá, a farinha tem grande destaque. Esta desponta como um gênero alimentício marcadamente amazônico que ajuda a compor, junto com outros tantos elementos de diferentes ordens, o saber, o fazer, a memória e a(s) identidade(s) das populações caboclo-ribeirinha paraenses. Caracteriza-se como um dos principais produtos de subsistência e também é geração de renda dessas populações.

No bairro do Guamá e adjacências, a Feira do Porto da Palha e a Feira da Farinha são espaços que cotidianamente recebem um grande fluxo de pessoas, até moradores de outros bairros, apresentando intensa e expressiva tradição social, cultural e econômica 
na venda da farinha, por isso foram escolhidas como locais para a realização das pesquisas deste trabalho.

A Feira da Farinha funciona no prédio do Mercado da Farinha, onde são negociados além da farinha, vários outros produtos. Esta fica localizada próxima ao Complexo de Abastecimento do Guamá, mais precisamente de esquina com as Avenidas Barão de Igarapé Miri e José Bonifácio. Funciona todos os dias, nos horários de 09:00 às 14:00, depois desse horário, a feira ainda funciona, mas com poucos feirantes trabalhando. Há dias que os feirantes chegam mais cedo, por volta de 05:00, para fazer o descarregamento da farinha que, geralmente, chega nos caminhões ou nos conhecidos "carros de mão" 5 " de madeira, quando vem dos portos.

Já a Feira do Porto da Palha, se localiza na intercessão dos bairros do Condor, Cremação e Guamá, às margens do Rio de mesmo nome, se dispondo em uma área que percorre porções da Avenida José Bonifácio e das ruas Bernardo Sayão e Padre Eutíquio, apresentando uma dinâmica um pouco diferenciada da encontrada na Feira da Farinha. Uma vez que esta tem como base de funcionamento o Porto da Palha, um ponto de embarque e desembarque dos mais variados produtos negociados na feira. Além dos feirantes residentes em bairros próximos, é possível visualizar "ribeirinhos, que desde as primeiras horas da manhã se aglomeram no pequeno trapiche oferecendo produtos por eles produzidos ou coletados no rio ou na floresta" (Silva, 2008: 3).

\section{Materiais e Métodos}

"O ciclo da pesquisa é um processo de trabalho em espiral que começa com uma pergunta e termina com um produto provisório capaz de dar origem a novas interrogações" (Minayo, 1994: 26). Porém, para se chegar a um produto faz-se necessário a utilização da metodologia. A metodologia, de acordo Dencker (1998), pode ser entendida como a ciência que edifica moldes estruturados que permitem abstrair informações de uma realidade a ser confirmada ou refutada.

Nisso, os procedimentos metodológicos servem para dar visibilidade a essa realidade construída, visto que a construção de conhecimento é estabelecida a partir de

\footnotetext{
${ }^{5}$ Espécie de veículo feito à madeira. "É usado no transporte de quantidade[s] elevada[s] de mercadoria[s] para embarque e desembarque no porto" (Leitão, 2010: 31) ou para o deslocamento de produtos do porto às feiras.
} 
embasamentos epistemológicos pré-existentes, definição de um método e aplicação de técnicas (Severino, 2007).

Em consonância com Dencker (1998), o método é a maneira ordenada de proceder a uma pesquisa, por meio da execução de atividades previamente definidas. As técnicas servem para abstrair informações da realidade a fim de identificar, analisar, diagnosticar e prognosticar respostas às problemáticas pesquisadas. Com isso, entende-se que a metodologia torna-se necessária para a descoberta de valores, caminhos e meios eficazes de compreensão da realidade investigada.

Diante do exposto, a metodologia de pesquisa empregada para a construção deste trabalho se estabeleceu por meio de uma abordagem qualitativa, que utilizou pesquisas bibliográficas, pesquisas documentais e pesquisas em campo. As pesquisas bibliográficas almejaram delimitar o objeto de estudo, construir embasamentos teóricos e categorizar conceitos como feiras, memória, saberes, identidades e farinha. Já as pesquisas documentais, permitiram coletar e analisar conteúdos já existentes, porém ainda não interpretados/discutidos (Severino, 2007).

As pesquisas em campo, por sua vez, realizadas por meio de uma aproximação etnográfica, tendo em vista que a etnografia, de acordo com Malinowski (1986), permite a criação de um contato mais estreito possível com os pesquisados, procurando, a partir da compreensão e, se possível, compartilhamento das experiências destes, "os imponderáveis da vida real", percebidos somente por meio do olhar holístico e minucioso durante a vivência, na ocasião em que ocorrem os fenômenos. Afinal, como assinala Martins (2000: 13):

São os simples que nos libertam dos simplismos, que nos pedem a explicação científica mais consistente, a melhor e mais profunda compreensão da totalidade concreta que reveste de sentido o visível e o invisível. O relevante está também no ínfimo. É na vida cotidiana que a História se desvenda ou se oculta.

A possibilidade de compreender e interpretar significados, simbolismos e as complexidades concebidas através de fenômenos ocorridos, única e exclusivamente, no local pesquisado, só é possível, segundo Clifford Geertz (2008), por meio da etnografia.

Para que a etnografia se consolide, é necessário que o pesquisador observe, se aproxime, viva, conviva, mantenha uma interação prolongada e cotidiana com os sujeitos e objeto de sua pesquisa - a fim de captar, de maneira densa, criteriosa e 
completa, as particularidades e os simplismos envolvidos no contexto e ao redor deste (Sato; Souza, 2001).

Dessa forma, entre os meses de outubro e maio de 2013/2014, por meio de incursões em campo, foi realizada uma observação participante na Feira do Porto da Palha e na Feira da Farinha, localizadas no bairro do Guamá. Nessas atividades de campo foi possível consolidar um contato cotidiano junto aos vendedores e compradores de farinha e demais derivados da mandioca, o que oportunizou a compreensão das relações estabelecidas no porto e feira do Guamá.

Como técnicas de pesquisas e coleta de dados, foram realizadas conversas, registros fotográficos, assim como, a aplicação de formulários e entrevistas, de modo a evidenciar os fenômenos estudados, capturar fenômenos pertinentes à discussão do problema abordado e compreender "o que os sujeitos pensam, sabem, [sentem,] representam, fazem e argumentam" (Severino, 2007: 124).

Inicialmente foi realizada a aplicação dos formulários, em que se pôde realizar um levantamento de todos os vendedores de farinha encontrados nos locais de pesquisa. Por meio dessa estratégia, foi possível estabelecer uma aproximação com os feirantes, realizar observações, conversas e registros fotográficos e fazer um diagnóstico socioeconômico dos vendedores. Este diagnóstico foi utilizado como parâmetro para a escolha dos entrevistados, sendo que pontos como: idade, tempo de trabalho com o produto, atenção, interesse e entusiasmo durante a primeira fase de pesquisa, foram os critérios seguidos.

Posteriormente, foram realizadas incursões em campo nas feiras e a aplicação de entrevistas com alguns feirantes, por intermédio dessas, se pôde capturar saberes e percepções desses agentes sociais, às mudanças que se desenharam nos processos de produção e comercialização de farinha, identificar a percepção e importância conferida a esse produto no processo de formação da identidade regional, bem como alcançar os demais objetivos deste estudo.

Os conhecimentos construídos, conteúdos trabalhados, dados e interpretações iniciais da pesquisa, foram expostos, debatidos e discutidos com pesquisadores do Projeto de Pesquisa Mercados Interculturais, discentes do Curso de Mestrado em Sociologia e Antropologia da Universidade Federal do Pará (UFPA) e com alguns dos vendedores de farinha que participaram das pesquisas, a fim de, a partir de opiniões, contribuições, sugestões, direcionamentos, críticas e considerações, desenvolver e 
amadurecer o trabalho. Afinal como bem pontua Tomazi (2007: 6) "todo conhecimento se desenvolve socialmente".

Os resultados aqui obtidos foram compartilhados junto aos feirantes participantes da pesquisa como uma forma de dar a eles um feedback, difundindo junto a estes os conhecimentos construídos por meio, principalmente, de suas memórias e percepções sobre as práticas relacionadas ao produzir, comercializar e consumir farinha. De modo que esta investigação científica de maneira alguma venha a ser considera "vampiresca", uma pesquisa "sanguessuga".

\section{Resultados e Discussões}

Todo dia, é dia de feira. É dia de venda.

Ainda está escuro, somente horas mais tarde é que terá início a feira, porém os "caboquinhos do interior" e os ribeiros - produtores e atravessadores - já começam a ancorar os seus barcos no porto ou estacionar os caminhões nas feiras, trazendo em suas "bagagens", os inúmeros gêneros alimentícios encomendados e que serão revendidos aos feirantes para abastecer a cidade.

Enquanto as horas vão se passando e os primeiros raios solares começam a rasgar os céus da cidade, as mercadorias vão sendo, pouco a pouco, descarregadas. Os feirantes, dali mesmo da Feira do Porto da Palha ou da Feira da Farinha ou de outras feiras, começam a chegar e procurar pelos barcos ou caminhões dos atravessadores de quem se encomendou ou pretende-se comprar os produtos que serão revendidos à sua clientela.

O corre e corre começa, as negociações vão rolando. Os carregadores, atentos às vendas já feitas, começam a se oferecer para levar os produtos adquiridos pelos feirantes até as feiras onde ficam as suas barracas - serviço feito por alguns trocados. Alguns feirantes de locais de venda distantes, se organizam e transportam as mercadorias ali adquiridas em "Kombi's" fretadas. Saem dali com muita correria, afinal a feira tem que

\footnotetext{
6 "Caboquinho", caboclo: são conhecidos como àqueles que moram em municípios rurais do Estado do Pará. Sendo, muitas vezes, o ribeirinho denominado assim.
} 
estar pronta até o amanhecer. As frutas, legumes, peixe e a farinha ${ }^{7}$ precisam ser pesados, embalados e arrumados antes que os primeiros clientes comecem a chegar.

Antes mesmo do sol tomar o céu, depois de receber o que foi encomendado ou conseguir comprar bons produtos, os feirantes, alguns com a ajuda dos filhos, esposas ou maridos, começam a arrumar suas barracas e o que será vendido, para então esperar os primeiros clientes.

Na Feira do Porto da Palha e na Feira da Farinha, há continuamente uma circulação muito grande de trabalhadores, feirantes, produtores, carregadores de mercadorias, atravessadores e clientes, que diariamente estabelecem e (re)constroem sociabilidades permeadas por uma dinâmica marcada pela ruralidade dos interiores da Amazônia e a urbanização da cidade grande. Entre as saudações de "bom dia”, gestos, sons e cumprimentos, a feira começa a se formar.

A Feira do Porto da Palha (Figura 1) funciona todos os dias da semana nos horários de 7:00 às 18:00. Esses horários de funcionamento podem variar, dependendo do dia da chegada dos gêneros, isto é, normalmente cada gênero costuma chegar em um determinado dia da semana, mas não é regra.

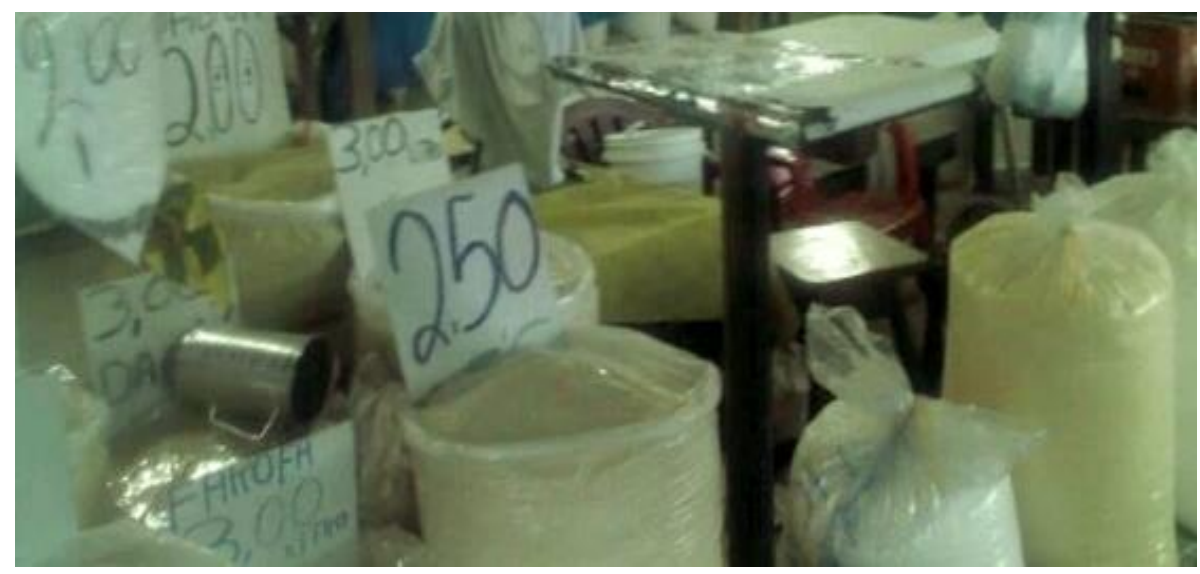

Figura 1 - Comercialização da farinha na Feira do Porto da Palha. Foto de Lobato, F. H. (2014).

A feira é perfilada num ambiente diferenciado das demais feiras do bairro, por ter como característica a proximidade com o rio, funcionando junto ao porto. A apresentação espacial é heterogênea, não há uma organização espacial em que se possa localizar as áreas onde cada gênero alimentício é comercializado, como acontecem em

\footnotetext{
${ }^{7}$ Existem diferentes tipos de farinha: seca, d'agua e mista, sendo a mais consumida pelos paraenses a d'agua, e seu processo de produção passa pelas etapas de: colheita, lavagem, amolecimento, ralamento, prensagem, peneiramento e torração.
} 
outras feiras. Assim, a feira se materializa no espaço pela sobreposição de barracas de madeira, pontos comerciais, pequenos mercados, bancas de ambulantes e estâncias.

A Feira da Farinha (Figura 2), por sua vez, funciona todos os dias com horários de 09:00 às 18:00. No período da tarde, costuma funcionar com poucos feirantes trabalhando. Há dias que os feirantes chegam mais cedo, por volta das 05:00, para comprar e fazer o descarregamento da farinha, que é comprada ou encomendada junto aos atravessadores.

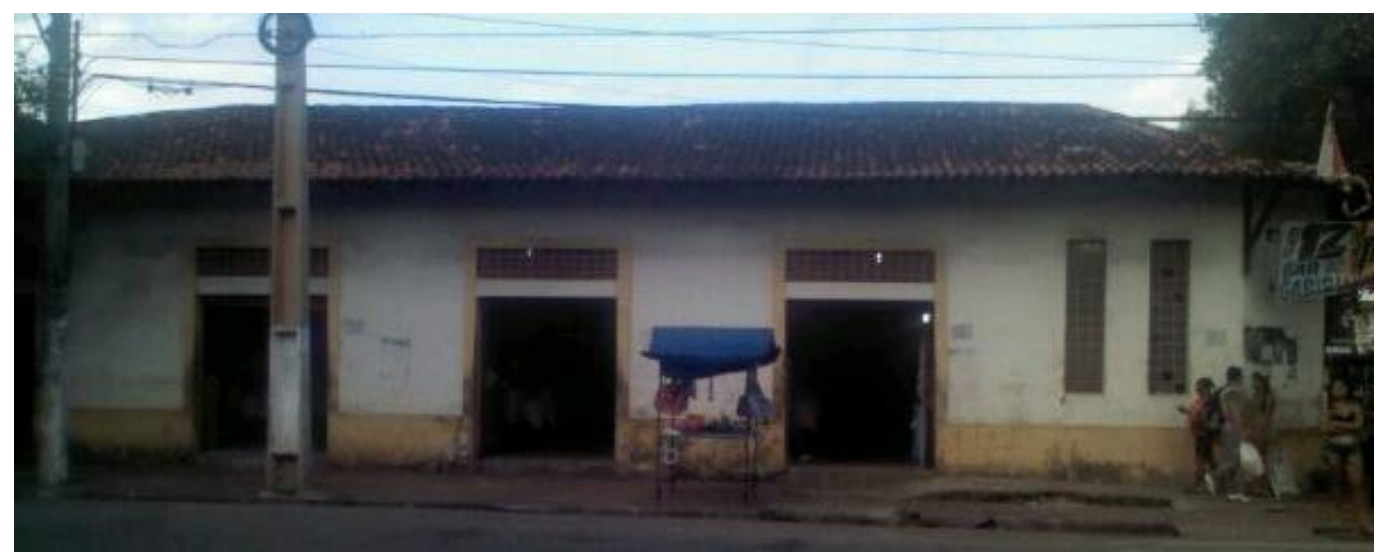

Figura 2 - Feira da Farinha. Foto de Lobato, F. H. (2014)

Em barracas de tamanho variados, armadas ou fixas nas extremidades das ruas que compreendem a Feira do Porto da Palha, a farinha é vendida em "sacos" ou "sacas" de plásticos com tamanhos que variam entre $1 / 2$ e 60 quilos, assim como os preços variam entre $R \$ 2,30$ e $R \$ 120,00$ reais.

$\mathrm{Na}$ Feira da Farinha, a farinha é comercializada nos chamados "pontos", demarcados pela disposição das sacas de farinha, em formato de retângulo com medições de $2 \mathrm{~m} \times 1 \mathrm{~m}$, sobre estruturas pequenas feitas de madeira. Sendo vendida em "sacas" de plástico padronizadas de 30 e 60 quilos ou sacos plásticos comuns de 1/2, 1 e 3 quilos (como mostram as Figuras 3 e 4) com preços que variam de R\$3,00 a R\$ 130,00 reais. 


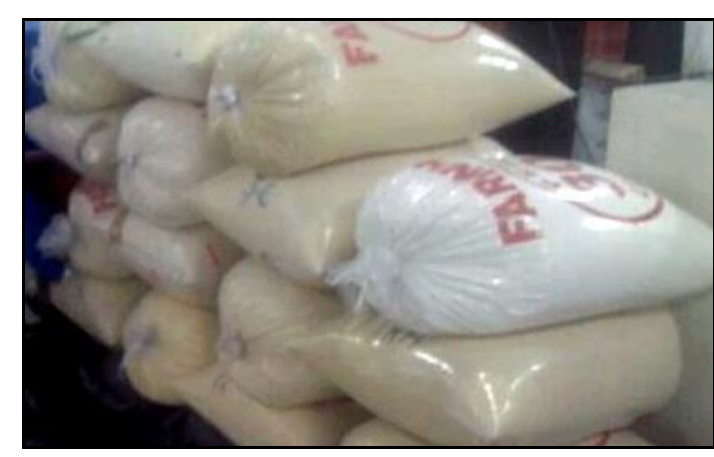

Figura 3 - Sacas de Farinha.

Foto de Lobato, F.H. (2014)

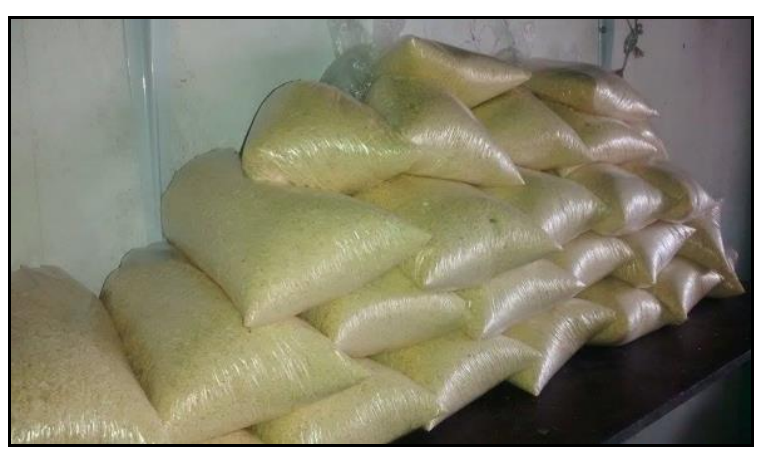

Figura 4 - Sacos de Farinha. Foto de Lobato, F. H. (2014)

Além da farinha, os fregueses, como são chamados os consumidores, também podem encontrar outros produtos derivados da mandioca, como: a goma de tapioca, a farinha de tapioca e a farofa. A farinha d'agua dentre as três opções de farinha existentes - seca (pura), mista e d'agua - é a mais vendida, de acordo com as respostas dos feirantes, é a que "o pessoal mais gosta", "é a melhor", "mais gostosa”, por isso é a preferida dos consumidores.

\section{Os feirantes da farinha}

Entre os feirantes destas feiras, foram encontrados um total de 29 (vinte e nove) vendedores de farinha. Na Feira da Farinha, existem 18 (dezoito) vendedores e 11 (onze) na Feira do Porto da Palha. Destes, 22 (vinte e dois) aceitaram participar da pesquisa, todos eles trabalham há mais ou menos seis anos como vendedores de farinha - o mais antigo vendedor, o senhor Dazalvo Oliveira, trabalha com a farinha há 35 anos, seja na condição de produtor ou vendedor. Dentre os que participaram da pesquisa, 17 (dezessete) pertenciam ao sexo masculino e 5 (cinco) ao feminino, com idades que variavam de 30 a 73 anos.

Notadamente, se pode visualizar uma disparidade acentuada entre homens e mulheres vendendo farinha. Tal fato é explicável devido à produção e venda deste produto demandar muito esforço físico, onde diariamente "sacas de farinha", com pesos que variam entre 30 e 60 quilos, são carregadas para a arrumação e guarda nas barracas. O fator idade, expresso nos números, demonstra que vender farinha como bem disse um dos feirantes ao ser questionado sobre a ausência de jovens, "não enche os olhos dessa juventude. Sempre que os meus [filhos] estão em casa sem fazer nada, eu costumo trazer eles para me ajudar". 
Sobre o nível de escolaridade, os formulários apontaram que 12 (doze) não concluíram o Ensino Fundamental, 4 (quatro) concluíram o Fundamental, 2 (dois) possuem o Ensino Médio incompleto e apenas 4 (quatro) conseguiram concluir o Ensino Médio. Destes, todos conheciam as etapas de produção da farinha, tendo apenas 2 feirantes nunca participado da produção do produto.

No que diz respeito à viabilidade econômica da profissão, segundo os feirantes a produção e/ou a comercialização da farinha e outros derivados da mandioca, não constituem ocupações que apresentam uma boa rentabilidade. Os ganhos estimados pelos entrevistados com a venda da farinha e demais derivados da mandioca, giraram em torno de $\mathrm{R} \$ 200,00$ e $\mathrm{R} \$ 1.500,00$ reais mensais. Valores que, para alguns deles, não são suficientes para custear as despesas, por este motivo 11 (onze) feirantes, além de trabalharem na feira, desempenham outras ocupações laborais para garantir o sustento de suas famílias. Entre as ocupações foram mencionadas: garçom, mecânico, vigilante, diarista, marceneiro, pintor e pedreiro.

\section{Trajetórias e memórias}

Com trajetórias regadas a muitos altos e baixos, passando por crises e tempos de grande fartura, as histórias daqueles que nas feiras tentam ganhar o "pão de cada dia" são marcadas por experiências de trabalho árduo pelos interiores do estado do Pará, seja na roça (na plantação e colheita de gêneros alimentícios), na produção de farinha ou na busca, floresta adentro, por animais que pudessem servir de alimento para saciar a fome. São trajetórias diversas, porém, incontestavelmente, sofridas.

No que se refere à memória que vendedores de farinha em portos/feiras do bairro do Guamá (PA) apresentam sobre os processos de produção, comercialização e consumo desse produto, durante as entrevistas realizadas, muitos feirantes disseram não lembrar muito das práticas ligadas à produção do gênero, apesar de grande parte já ter participado ou presenciado a produção de farinha. Sobre isto, Santos (2003: 274) discorre que:

Nós não somos capazes de lembrar com todos os detalhes nem mesmo um evento vivenciado algumas horas atrás. Se nos damos conta de que, além de ser seletiva, a memória envolve o esquecimento, podemos compreender melhor ainda a falta de controle que temos sobre ela, pois o que lembramos e esquecemos não é resultado apenas de nossas intenções e desejos declarados. Nós nos lembramos de detalhes 
aparentemente sem importância e esquecemos de faces, nomes e lugares que seriam fundamentais para nós. O esquecimento de experiências traumáticas pode acontecer independentemente de nossas vontades.

Deste modo, percebe-se que as memórias são falhas e incompletas. No entanto, Santos (2003: 274) pontua que "a memória tanto está presente em nós, quanto é, também, exterior a nós. Há objetos que guardam a memória e nos fazem lembrar das mais diversas maneiras". Nesta direção, a autora também assinala que "a memória se cristaliza fora de nós, em lendas, monumentos e objetos que estão longe de ser reflexos de verdades históricas". Contudo, sinaliza que, apesar da memória se cristalizar em objetos, isso "não supera o fato de que a memória como relato do passado é falha e incompleta" (Santos, 2003: 274). Aliado a isso, com as transformações da sociedade atual muitos desses objetos, lendas e monumentos estão sendo esquecidos, deixados de lado e até substituídos, o que tem ameaçado e até dizimado às memórias - já falhas e incompletas por "natureza" - de forma significativa.

Segundo alguns dos feirantes, os seus pais, mães e avós poderiam relatar melhor, com uma maior riqueza de detalhes as práticas ligadas à farinha, pelo fato de terem trabalhado durante muito tempo na produção e comercialização do produto. Porém, eles não trabalham mais na venda da farinha por estarem muito idosos ou já terem falecido. Entre as repostas, Elias, disse que "quem poderia te falar melhor isso era o meu pai, mas ele já faleceu”. Este cenário demonstra o que Frazer (2005) salientava sobre o fato de que as histórias e as memórias estarem morrendo juntamente com as gerações mais antigas. O presente, portanto, compreendido por intermédio da reconstrução do passado (Santos, 2003), passa a não ter sentido.

Por outro lado, entendendo as memórias como "resultado de experiências vivenciadas e que estas deixam poucos traços de si em nós" (Santos, 2003: 275), conseguiu-se registrar uma pequena parcela da memória que está sendo esquecida. As lembranças entre os feirantes revelam que as práticas atreladas à produção da farinha, no interior do estado do Pará, era (e ainda é) realizada de maneira artesanal nas "casas de farinha". Produzir farinha é uma ocupação repassada de pai para filho, Dezalvo Oliveira, 73 anos, conta que seus pais e avós "trabalhavam [com a produção da farinha], eu aprendi a produzir e a vender farinha com a minha mãe”.

Dona Maria, conta que na infância lembra que para produzir farinha, 
produzir farinha, tem muitas, como é que eu posso falar, etapas. Tem que ter força, muita força. Tem que carregar a mandioca, depois cortar, descascar, lavar, deixar de molho, né? Depois espreme aquela massa, no tipiti, enfim é tudo muito difícil (...). Uma das partes mais bonitas, já é no final, quando se tá mexendo, torrando a farinha. Eu lembro que eles jogavam ela [a farinha] pra cima, era muito bonito".

Observa-se que o ato de produzir farinha, na comunidade onde Dona Maria nasceu e viveu boa parte de sua juventude, é uma atividade que envolvia várias famílias e que demanda esforço físico, como também sinaliza "Seu Jailton", como é chamado, ao lembrar que produzir farinha "é um trabalho muito cansativo. Quem sai de lá [quem sai da condição de produtor de farinha] não quer mais voltar".

Sobre as trajetórias até a feira, Mauricio contou que:

Nasci em Castanhal [Estado do Pará], lá a minha família toda trabalhava e ainda trabalha com a plantação da mandioca e a produção da farinha. Mas trabalha também com outros alimentos. Lá eu aprendi a produzir farinha, e às vezes vinha pra cá [Belém] junto com o meu tio vender farinha. A gente ia e vinha toda a semana pra cá. Nessa época eu tava terminando o meu ensino, segundo grau. Quando eu terminei, vim de vez pra cá [Belém] com outro tio meu, ele já trabalhava vendendo farinha, mas não era aqui [Feira da Farinha], era na casa dele mesmo, e como eu morava com ele, eu ajudava ele a vender. Até que o meu tio conseguiu esse ponto aqui e como eu fiquei vindo pra cá com ele, antes dele morrer, ele deixou pra mim [...]. É a gente sempre pega a farinha lá de Castanhal mesmo, mas também de outros lugares, por que os clientes gostam muito da [farinha] de Bragança.

Apesar de alguns participantes da pesquisa serem naturais de Belém, a maioria nasceu nos municípios do interior do estado, como: Castanhal, Vigia de Nazaré, Inhangapi, São Francisco do Pará. E, por isso, possuem fortes relações com as populações produtoras de farinha. Relações estas, em alguns casos, de parentesco, em que a família (os país, avós e irmãos) é a produtora da farinha comercializada pelo feirante. As redes de circulação econômica que ser formam no processo de comercialização da farinha são ocasionadas também por esta forte e estreita relação existente entre produtores e vendedores.

Entre os outros vendedores se constatou que conseguir um espaço para vender farinha é muito difícil, uma vez que os chamados "pontos de venda" e as barracas podem ser "conquistadas" somente através de heranças ou compra e venda. Há casos, na Feira do Porto da Palha, em que pode-se conseguir um lugarzinho para armar a sua barraca e ali começar a vender. No entanto, além de sofrer sanções do órgão responsável pela fiscalização das feiras, há também, por parte dos próprios feirantes que não querem "mais um na concorrência". 
Assim, para disputar por um "lugarzinho" ou um "ponto", apesar de ser difícil, não é a pior parte, pois permanecer e manter aquilo que se conquistou é um desafio bem maior, uma vez que a venda na feira é uma constante "tem dia que dá, mas tem dia que não" comenta José Maria. Aliado a isso, as normas de funcionamento, sobretudo as de higiene, são desafios, principalmente quando se trabalha em uma feira livre, como é o caso da Feira do Porto da Palha.

\section{Comercialização e consumo}

Para a clientela que ali chega é impossível não se encantar e ter os sentidos apurados com tamanha variedade, riqueza e junção de tantos sons, aromas, sabores e cores em um mesmo espaço. Entre os tantos artigos e gêneros alimentícios comercializados, a farinha desponta como um dos principais produtos por compor a alimentação tradicional do paraense.

Cada feirante usa e tem uma tática ou um jeito de chamar a atenção e convencer o cliente a adquirir o produto. Do bate palma ao grito anunciando a procedência da farinha vendida, cada um ganha o seu cliente. Como grita Dona Isabel: "Olha a farinha, olha a farinha. Essa é de Bragança! Pode provar meu amor, pode provar”.

Mas só isso não basta para convencer o cliente, entre os relatos, um feirante precisa demonstrar "carisma", "atenção", "boa educação", "receptividade", "alegria" etc. Jorge, 35 anos, diz que para convencer o cliente a comprar a farinha, "tem que fazer o comercial. Oferecer um produto de qualidade. Não enganar o cliente, pois você sempre precisa do cliente". "Tem que falar que é um produto de qualidade, é a melhor [farinha] que tem", comenta Janilson. Já Elias, procura “[...] comprar a mercadoria a gosto do cliente. Tratamento e educação são fundamentais na hora [da venda]".

Sobre a comercialização da farinha, durante o tempo em que trabalha como vendedora, Mariléia, 53 anos, lembra que "antigamente as embalagens eram trazidas pelos próprios clientes. Era legal, a gente gastava menos [risos]". Ainda durante o período de trabalho, alguns fatos inusitados aconteceram com os feirantes, dentro das sacas de farinha já foram encontrados copos, talheres e outros objetos: "Eu já encontrei até um prego, uma vez. Todo mundo ficou me 'encarnando"8 aqui', disse Elias.

\footnotetext{
${ }^{8} \mathrm{Na}$ linguagem do paraense significa dizer que um indivíduo sacaneia, brinca, tira ou faz graça com o outro.
} 
Ao abordar acerca da importância que a farinha representa para os feirantes, através das respostas da expressiva maioria dos entrevistados, observou-se que a farinha representa e compõe a renda do trabalhador, mesmo o lucro durante alguns meses sendo pequeno. Mais do que a importância econômica, a farinha também se apresenta como essencial na vida do paraense, pois ele compra "por que ele é papa-chibé”, "a farinha é tudo para o paraense". É um complemento alimentar que “dá sustância ao paraense", assinala Isabel.

Nesse sentido, pontua-se que além do aspecto econômico, a farinha é visualizada como componente da identidade do paraense, que ajuda a compor a identidade PapaChibé. Esta acompanhada do açaí não pode faltar na hora do almoço, sendo, portanto, procurada pelo consumidor diariamente nas feiras. Ademais, a farinha e as práticas que a envolvem trazem a muitos dos atuais habitantes da cidade grande, lembranças de suas histórias vivenciadas ou narradas por seus parentes há algum tempo atrás, nas margens dos rios da milenar Amazônia. Assim, os produtores e vendedores de farinha assumem um caráter essencial na composição da alimentação e manutenção da identidade cultural do paraense.

Contudo, nos últimos anos alguns fatores têm ocasionado mudanças significativas nas condições necessárias para a produção da farinha, limitando sua produção, o que tem gerado, por sua vez, alterações na oferta deste gênero nos portos, mercados e feiras de Belém, bem como nos diferentes modos de consumo e na cultura do povo paraense. De acordo com os feirantes participantes da pesquisa e com o apoio de pesquisas bibliográficas e documentais, pode-se evidenciar que os fatores motivadores destas mudanças, são: a desenfreada pressão sobre as fronteiras, a diminuição de terras disponíveis às populações tradicionais e luta por elas na Região Norte do Brasil. Isto tem impedido os pequenos produtores de aumentar a produção e até limitado e diminuído as áreas de plantio da mandioca, o que tem gerado, por conseguinte, efeitos na produção da farinha e de outros derivados da mandioca.

Os benefícios pagos pelo Governo têm contribuído de certa forma na renda das famílias, e já não há tanta necessidade de produzir farinha para venda, apenas para consumo próprio. Nesta perspectiva, Francisco disse que a farinha teve alta em seu preço: “[...] depois que o pessoal começou a receber esse negócio de bolsa família,

\footnotetext{
${ }^{9}$ Mesmo que sustância, energia, força, etc.
} 
pararam de produzir. O povo se acomodou. Já não tem mais tanta necessidade assim. Numa dessa, até eu parava”.

As novas gerações, filhos e netos de produtores e vendedores, não sentem vontade e não se veem trabalhando da mesma maneira que os pais, pois as práticas ligadas à produção e comercialização da farinha são ocupações cansativas, que demandam tempo e muito esforço físico. Muitos têm que deixar de produzir e comercializar farinha para sair do "interior" em busca de uma vida diferente de seus antepassados. As novas gerações têm buscado, na cidade grande, novas e melhores condições de vida.

Para além disso, segundo os feirantes, fatores como: a exportação da farinha para outros lugares; o fato do incentivo governamental, no sentido de apoio ao pequeno produtor, ainda deixar a desejar; as distâncias entre as regiões de produção e os pontos de venda na cidade, dificultam o escoamento e a existência de muitos atravessadores que estabelecem a oferta do gênero ao consumidor, têm contribuído para a carestia da farinha. Verificou-se ainda, que o produzir ao comercializar farinha têm sofrido significativas alterações diante dos processos de normatização impostos pelos processos sanitaristas que marcam a vida urbana.

Como efeitos dessas alterações na dinâmica de produção da farinha, houve altas inesperadas nos preços da farinha nas feiras, o que alterou as formas de consumo e de hábitos da cultura paraense. Neste sentido, de acordo com dados do Departamento Intersindical de Estatística e Estudos Socioeconômicos - DIEESE (2014), a partir de uma análise realizada sobre cálculo das médias anuais dos preços do quilo da farinha em Belém, nos últimos cinco anos (2009-2013) (Tabela 1), se observou que o aumento nesse período correspondeu a mais de $200 \%$. 


\begin{tabular}{|c|c|c|c|c|c|c|c|c|c|}
\hline 2009 & $\begin{array}{l}\text { Preço } \\
\text { médio }\end{array}$ & 2010 & $\begin{array}{l}\text { Preço } \\
\text { médio }\end{array}$ & 2011 & $\begin{array}{l}\text { Preço } \\
\text { médio }\end{array}$ & 2012 & $\begin{array}{l}\text { Preço } \\
\text { médio }\end{array}$ & 2013 & $\begin{array}{l}\text { Preço } \\
\text { médio }\end{array}$ \\
\hline Jan/09 & 2,26 & Jan/10 & 2,23 & Jan/11 & 2,87 & Jan/12 & 2,96 & Jan/13 & 6,06 \\
\hline Fev/09 & 2,24 & Fev/10 & 2,45 & Fev/11 & 2,77 & Fev/12 & 2,97 & Fev/13 & 6,83 \\
\hline Mar/09 & 2,07 & Mar/10 & 2,59 & Mar/11 & 2,73 & Mar/12 & 3,09 & Mar/13 & 7,41 \\
\hline Abr/09 & 2,14 & Abr/10 & 2,72 & Abr/11 & 2,74 & Abr/12 & 3,15 & Abr/13 & 7,55 \\
\hline Maio/09 & 2,13 & Maio/10 & 2,78 & Maio/11 & 2,69 & Maio/12 & 3,09 & Maio/13 & 7,85 \\
\hline Jun/09 & 2,1 & Jun/10 & 2,71 & Jun/11 & 2,67 & Jun/12 & 3,19 & Jun/13 & 7,81 \\
\hline Jul/09 & 2,09 & $\mathrm{Jul} / 10$ & 2,73 & Jul/11 & 2,65 & Jul/12 & 3,22 & Jul/13 & 7,06 \\
\hline Ago/09 & 2,12 & Ago/10 & 2,78 & Ago/11 & 2,81 & Ago/12 & 3,25 & Ago/13 & 6,64 \\
\hline Set/09 & 2,13 & Set/10 & 2,75 & Set/11 & 2,83 & Set/12 & 3,34 & Set/13 & 6,54 \\
\hline Out/09 & 2,12 & Out/10 & 2,74 & Out/11 & 2,89 & Out/12 & 4,17 & Out/13 & 6,19 \\
\hline Nov/09 & 2,11 & Nov/10 & 2,8 & Nov/11 & 2,88 & Nov/12 & 5,32 & Nov/13 & 6,24 \\
\hline Dez/09 & 2,12 & Dez/10 & 2,84 & Dez/11 & 2,92 & Dez/12 & 5,56 & Dez/13 & 5,84 \\
\hline Média & 2,135833 & Média & 2,676667 & Média & 2,7875 & Média & 3,609167 & Média & 6,835 \\
\hline
\end{tabular}

Tabela 1 - Média de preços, em reais, da farinha a quilo em Belém/PA de 2009 a 2013. Fonte: DIEESE. Adaptado por Lobato, F. H. (2014).

Os dados da Tabela 1 mostram que do ano de 2011 para 2012 houve um reajuste de $35 \%$ no preço da farinha. Contudo no ano de 2013, o preço do quilo da farinha teve um aumento de aproximadamente $80 \%$ em relação ao ano anterior, tendo este gênero alimentício em 2013, passado a ser o mais caro da cesta básica na capital, o que representou o maior reajuste na história da comercialização deste gênero. Esse crescimento pode ser melhor visualizado no Gráfico 1, abaixo.

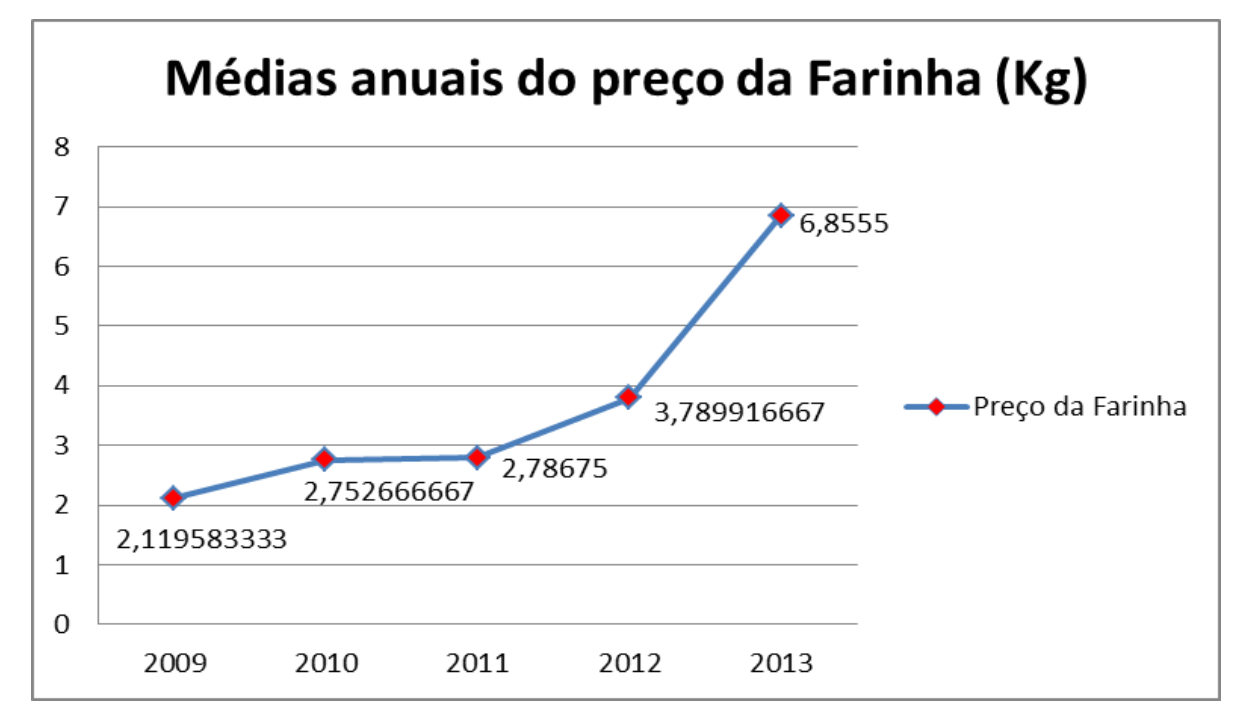

Gráfico 1 - Crescimento das médias anuais do preço do quilo da farinha. Fonte: Lobato, F. H. (2014). 
Para se ter uma noção do que representa os aumentos no preço da farinha, de acordo com o relatório de uma pesquisa realizada pelo DIEESE, “em cerca de 17 anos de Plano Real é só compararmos a subida da cesta básica no mesmo período. Enquanto a cesta subiu em média $289 \%$, a farinha de mandioca subiu cerca de $653 \%$ e a inflação em torno de $312 \%$ ". O relatório conclui que o preço farinha apresentou um crescimento superior à média da cesta básica e da inflação, da mesma época (G1 Pará, 2012).

Diante deste cenário, de conformidade com os vendedores, houve inúmeras reclamações e questionamentos dos consumidores sobre os repentinos aumentos no preço da farinha. As principais reclamações e indagações, como contaram os feirantes, foram: "O que tá acontecendo?" "Querem ficar ricos é?" "Por que a farinha tá tão cara?" "Égua, desse jeito num dá!" "Me veja só 2 quilos então!”.

Neste sentido, com o aumento da farinha, segundo Silva e Costa (2013) as redes sociais serviram como o palco principal das reclamações e indagações acerca do aumento do produto, através de um grande número de postagens sobre o assunto. Ainda segundo os autores, "as mídias sociais passaram a ser o cenário de manifestações, piadas e reflexões sobre as consequências do aumento do custo da farinha na identidade cultural dos paraenses" (Silva; Costa, 2013: 3) e são até hoje. A Figura 5, a seguir, por exemplo, demonstra isto.

$\mathrm{Na}$ imagem, a postagem feita pela fanpage "Orgulho de ser paraense" lembra o tempo em que o quilo da farinha custava apenas $\mathrm{R} \$ 1,00$. Nos comentários é possível observar alguns paraenses expressando suas opiniões sobre inúmeros aspectos ligados à farinha. A primeira internauta fala sobre um dos possíveis fatores que contribuíram para o aumento no preço do gênero, os demais comentam sobre a nostalgia que sentem do tempo em que o preço da farinha era mais em conta. 

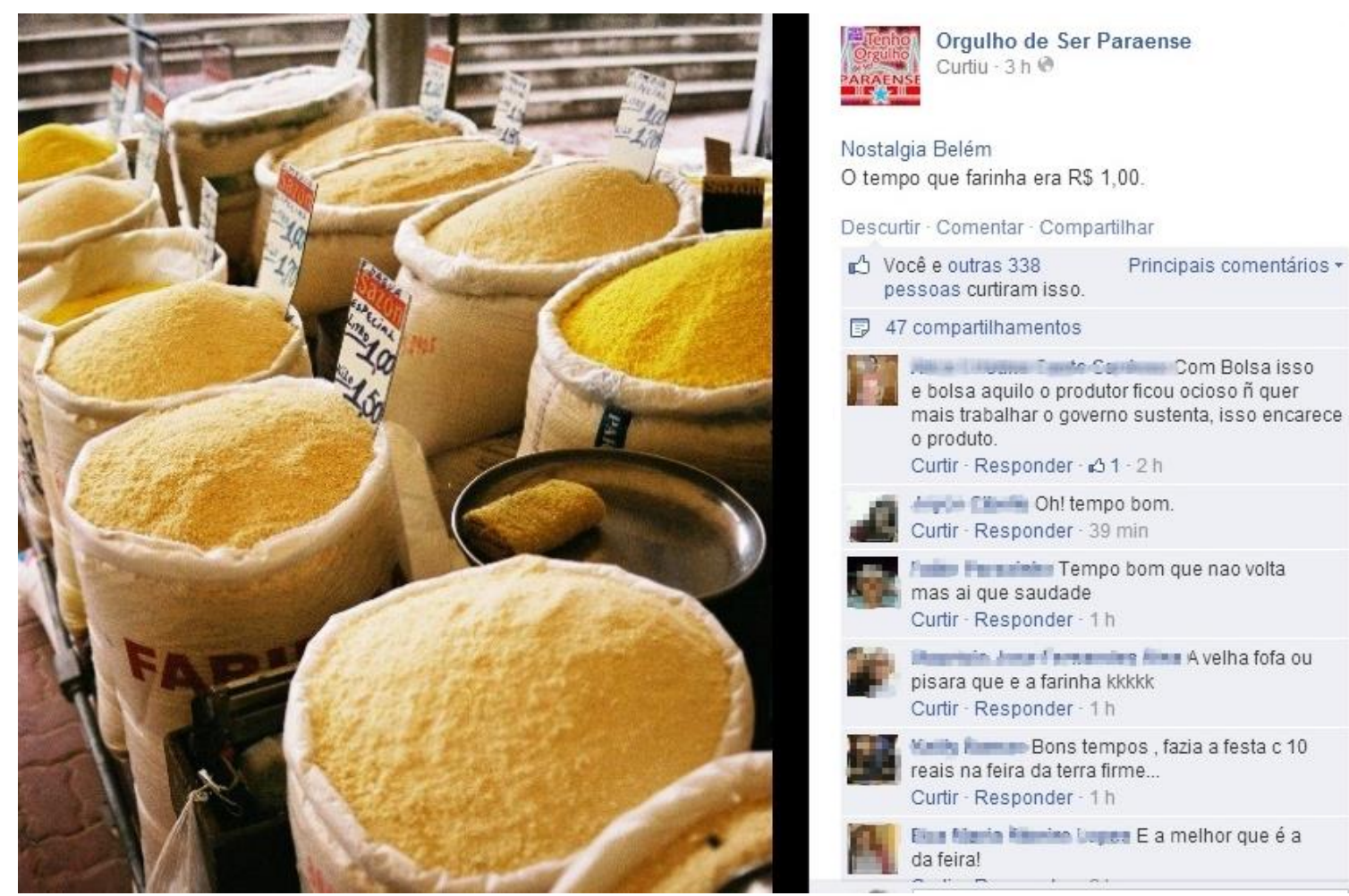

Figura 5 - Manifestações sobre o preço da farinha na internet. Fonte: Captura de tela (print) da rede social, Facebook, Lobato, F. H. (2014).

Ainda diante deste quadro, segundo os vendedores, o fluxo de compra foi mantido, o que gerou - muitas vezes - filas grandiosas, como falou José Maria: “às vezes, vinha pouca farinha, aí tinha[m] filas enormes aqui. Mas mesmo assim o pessoal ainda vinha procurar farinha pra comprar". Janilson conta que de fato "eles [os clientes] não sumiram, $[\ldots]$ mas compravam em poucas quantidades. Quem comprava 5 quilos, passou a comprar só 1". Devido aos altos valores, Mauricio disse que "o consumidor paraense começou a substituir a farinha por outros alimentos, como o arroz".

Mesmo com o barateamento do produto, através dos relatos de vários feirantes pode-se compreender que a farinha, ainda que muito procurada pelo paraense nas feiras, nunca mais foi vista com os mesmos olhos. Antes era conferida a ela uma maior importância, hoje, mesmo gostando do produto, alguns consumidores parecem não atribuir ou ver a farinha com a mesma importância que antes, como sinaliza o breve relato de Dona Isabel: "Antigamente, meu filho, eu não sei, mas me parece que os pessoal [as pessoas] davo [davam] mais importância pra [para a] farinha, sabe. Hoje em dia, vem gente comprar, mas não é a mesma coisa”. Nessa linha, José Maria fala que "os mais antigos, nossos pais e avós davam mais importância que a gente [para a farinha]". 
Essas mudanças vêm desenhando novos processos de identidade, antes fortemente marcados pela farinha enquanto um integrante condutor. As praticas de produzir, comercializar e consumir farinha tem perpassado por significativas mudanças, alterando de forma súbita a memória e identidade do paraense, levando ao que Hall (1992) denominaria de "crise de identidades".

Estes processos, aliados ao que se observa no atual contexto mundial, estão transcorrendo profundas mudanças estruturais, em que a indústria cultural, com sua abrangência globalizadora, tem se projetado em regiões mais tradicionais e forçado estas a incorporar modelos culturais padronizados, que propiciam a cada dia a substituição das essências singulares, que compõem a identidade cultural dessas localidades.

Destarte, ainda que pequenas comunidades pelos interiores do Estado resistam e continuem a produzir e os feirantes continuem comercializando a farinha, a identidade, memória e cultura "papa chibé" está se "transformando" de forma substancial e passa por uma verdadeira crise em si mesma.

Nessa perspectiva, Miranda (2000) assinala sobre a identidade, dizendo que esta não pode ser entendida enquanto plena, estática, uma vez que os processos de construção, desenvolvimento e incorporação de novas identidades são naturais, tendo em vista que a cultura é dinâmica. No entanto, é válido ressaltar que esses processos e as novas incorporações, aqui pontuados, não são "naturais". Dessa forma, antes que se transforme por completo, é necessário que mais e mais pesquisas como esta possam se realizar, a fim de registrar o que ainda resta da cultura cabocla-ribeirinha existente na milenar Amazônia.

\section{Conclusão}

As feiras do Porto da Palha e da Farinha são espaços em que diariamente um grande fluxo de pessoas transita. Dentre os tantos produtos dispostos à venda, estas feiras apresentam expressiva tradição cultural e econômica na venda da farinha, um gênero alimentício marcadamente amazônico, que se caracteriza como o principal produto de subsistência e geração de renda das populações beneficiadas por ela.

Não obstante, a farinha e as práticas culturais que a envolvem têm sofrido fortes interferências em seus processos produtivos, cujos motivos se apresentam sob diferentes aspectos. Esses processos têm sua formação nas praticas de produzir farinha e vem se 
desenhando em demasia sobre os preços e, por conseguinte, nas formas de comercialização e consumo do produto, bem como na memória e identidade do paraense inserido nesses procedimentos.

Diante deste cenário, buscou-se tentar responder neste trabalho, qual a memória e os processos identitários que os vendedores de farinha, em portos/feiras do bairro do Guamá na cidade de Belém (PA), apresentam sobre os processos de produção, comercialização e consumo desse produto?

Assim, a partir do caminho metodológico percorrido, no que se refere à memória, muitos feirantes afirmaram não lembrar-se de muita "coisa" sobre as práticas ligadas à produção do gênero, outros informaram que os seus pais, mães e avós poderiam relatar melhor, com uma maior riqueza de detalhes, porém estes não trabalham mais com a venda da farinha por estarem bem idosos ou já terem falecido. Esse contexto demostra o que Frazer (2005) salientava sobre histórias e memórias que estão a morrer juntamente com as gerações mais antigas.

Entre alguns feirantes, ainda existe uma parcela da história que está sendo esquecida. Neste sentido, sobre os processos de produção de farinha, as lembranças de alguns deles revelam que as práticas atreladas à produção da farinha no interior do estado do Pará, eram e ainda são realizadas de forma artesanal nas "casas de farinha". Essa atividade envolvia (e envolve) a participação de várias famílias, pois as etapas são longas e trabalhosas. Produzir e comercializar farinha são ocupações normalmente repassadas de pai para filho, uma tradição.

No que concerne à memória sobre a comercialização da farinha, lembrou-se que em outros tempos os clientes ao comprar farinha, já traziam de suas residências embalagens ou os recipientes onde já se armazenava a farinha. Durante o tempo em que trabalham como feirantes, muitos fatos inusitados aconteceram, entre eles, já foram encontrados diversos objetos dentro das "sacas" de farinha, sendo o mais improvável, um prego.

Sobre os processos identitários que os feirantes apresentam acerca dos processos de produção, comercialização e consumo da farinha, evidenciou-se por meio das entrevistas, que a farinha é um importante componente na renda do trabalhador, todavia, mais que a importância econômica, a farinha também se apresenta como essencial na vida e no universo cultural do paraense. 
Deste modo, nota-se que além do aspecto econômico, a farinha é visualizada como componente da identidade do paraense. Com base nos relatos, é ela quem forma a identidade papa chibé, acompanhada do açaí, que não pode faltar na hora do almoço. Além disso, a farinha e as práticas que a envolvem trazem, para muitos dos atuais habitantes da cidade grande, lembranças de suas histórias vivenciadas ou narradas por seus parentes há algum tempo atrás, afirma-se isso com base nas informações dispostas pelos entrevistados. Assim, os produtores e vendedores de farinha assumem um caráter essencial na composição da alimentação e manutenção da identidade cultural do paraense "papa chibé".

No entanto, o preço da farinha nos últimos cinco anos, sofreu reajustes intensos, decorrentes das condições de produção do gênero. De acordo com o que pôde ser levantado, a carestia do produto se deu porque a produção é realizada por pequenos produtores, que possuem poucas terras, lutam por elas, têm poucos recursos, executam suas funções de forma artesanal nas "casas de farinha", dentre outros fatores, o que resulta em uma produção de pequena escala. Esses fatores, somados a outros evidenciados durante a pesquisa, como: exportação, existência de muitos atravessadores e grandes distâncias das regiões produtoras e a capital, etc. - influenciam diretamente nos preços do mercado econômico e cultural da farinha.

Nesse cenário, muitas reclamações começaram a surgir da parte dos consumidores, tendo as redes sociais constituídas como espaços para várias manifestações e indignações a respeito do preço da farinha. Vale ressaltar que, de acordo com os feirantes, apesar do aumento, o fluxo de consumidores não diminuiu, porém estes passaram a adquirir o produto em menores quantidades.

Apesar do barateamento do produto neste ano (2014), através dos relatos de vários feirantes, pôde-se compreender que a farinha, ainda que muito procurada pelo paraense, nunca mais foi vista com os mesmos olhos. Antes era conferida a ela uma maior importância, hoje, mesmo gostando do produto, alguns consumidores parecem não atribuir ou não ver a farinha com a mesma importância que antes. Isso porque a farinha passou a ser substituída por outros produtos bem mais em conta.

Essas mudanças que vêm se desenhando sobre as praticas de se produzir, comercializar e consumir farinha têm desencadeado, de forma súbita, significativas alterações na memória e identidade do paraense conhecido como "papa chibé”. Isto gera novas identificações e formas de pertencimento, levando ao que Hall (1992) denominaria como "crise de identidades". 
Diante dos resultados alcançados, este estudo se mostra um importante referencial teórico para outras pesquisas, pois resgata uma parcela do que ainda resta da memória de feirantes e os processos identitários que possuem sobre os meios ligados a farinha. Ressalta-se que novos estudos poderão contribuir para uma coleta de dados e análises mais profundas dos resultados.

\section{Referências}

BELÉM. Secretaria Municipal de Coordenação Geral do Planejamento e Gestão. Anuário estatístico do município de Belém 2010, v. 15, Belém, 2010. Disponível em: <http://www.belem.pa.gov.br/app/c2ms/v/?id=1\&conteudo=2995>. Acesso em: 08 dez. 2013.

CARNEIRO, E.; OLIVEIRA, S. A. D.; CARVALHO, K. D. Turismo cultural e sustentabilidade: uma relação possível? Revista Eletrônica de Turismo Cultural, São Paulo, v. 7, 2010.

CRUZINHA, M. N. Precarização das condições de trabalho independente e informalidade faces e disfarces: o caso dos jovens feirantes do Bairro do Guamá. Belém, 2003, 131f. (Dissertação de Mestrado em Sociologia) Departamento de Sociologia, Centro de Filosofia e Ciências Humanas, Universidade Federal do Pará, Belém, 2003.

DEPARTAMENTO, Intersindical de Estatística e Estudos Socioeconômicos (DIEESE). Cesta Básica de Alimentos In:___ Banco de Dados. Disponível em: <http://jboss.dieese.org.br/cesta/>. Acesso em: 29 abr. 2014.

DENKER, A. F. M. Métodos e técnicas de pesquisa em turismo. São Paulo: Futura, 1998.

FRAZER, J. G. “O escopo da antropologia social”. In: CASTRO, C. (Org.) Evolucionismo cultural: textos de Morgan, Tylor e Frazer. Rio de Janeiro: Zahar Editores, p. 101-127, 2005.

FREITAS, C. R. B. O Mercado municipal de Campos dos Goytacazes: a sedução persistente de uma instituição pública. Rio de Janeiro. 2006. (Dissertação de Mestrado em Políticas Sociais) Centro de Ciências do Homem da Universidade Estadual do Norte Fluminense Darcy Ribeiro, Rio de Janeiro. 2006.

G1 PARÁ. Açaí e farinha de mandioca ficam mais caros em Belém, revela Dieese. Pará, 2012. Disponível em: <http://g1.globo.com/pa/para/noticia/2012/04/acai-e-farinha-de-mandiocaficam-mais-caros-em-belem-revela-dieese.html> Acesso em: 13 mar. 2014.

GEERTZ, C. A interpretação das culturas. 1 ed. 13ª Reimpressão. Rio de Janeiro: LTC, 2008.

HALL, S. A identidade cultural na pós-modernidade. Rio de Janeiro: DP\&A. Editora, 1992.

INSTITUTO, Brasileiro de Geografia e Estatísticas (IBGE). Dados do Sistema. Disponível em: <http://cidades.ibge.gov.br/xtras/perfil.php?lang=\&codmun=150140\&search=para|belem>. Acesso em: 30 set. 2013. 
LARAIA, Roque de Barros. Cultura: um conceito antropológico. Rio de Janeiro: Jorge Zahar, 1997.

LEITÃO, W. M. (Org.). Ver-o-Peso: estudos antropológicos no mercado de Belém. Belém: NAEA, 2010.

LOBATO, F. H. S.; AIRES, J. C. A.; RAVENA-CAÑETE, V.; A ausência do (des) envolver dos espaços de lazer: do centro urbano às áreas periféricas de Belém (PA). In: IX Turismo em Debate, 2013, Belém. Anais. Belém, 2014.

MALINOWSKI, B. Introdução: o assunto, o método e o objetivo desta investigação [Argonautas do Pacífico Ocidental]. In: DURHAM, E. (Org.) Bronislaw Malinowski. São Paulo: Ática, Coleção Grandes Cientistas Sociais, p. 24-48, 1986.

MARTINS, J. D. S. A sociabilidade do homem simples. São Paulo: Editora Contexto, 2010.

MEDEIROS, J. F. S. “As feiras livres em Belém (PA): possibilidades e perspectivas de (re) apropriação do território na cidade". In: EGAL (Encuentro de Geógrafos de América Latina), 2009, Montevideo. Caminando en una América Latina en transformación. Montevideo, 2009.

MINAYO. M. D. S. "Ciência, técnica e arte: o desafio da pesquisa social". In: et al. (Org.). Pesquisa Social: Teoria, métodos e criatividade. Petrópolis: Vozes, p. 9-29, 1994.

MIRANDA, A. "Sociedade da informação: globalização, identidade cultural e conteúdos". In: Ciência da Informação. Brasília, v. 29, n. 2, p. 78-88. 2000. Disponível em: <http://repositorio.unb.br/handle/10482/629> Acesso em: mai. 2014.

MOTT, L. "Feiras e mercados: pistas para pesquisa de campo". In: FERRETTI, S. (Org.). Reeducando o olhar: estudos sobre feiras e mercados. São Luiz: Edições Universidade Federal do Maranhão, 2000, p. 13-34.

NASCIMENTO, L. T. A. D.; RODRIGUES, C. I. "Sociabilidades no mercado de peixe do Vero Peso: das práticas cotidianas à festa de Nossa Senhora de Nazaré”. In: Revista Pós Ciências Sociais. V.8, nº 16. São Luis. p. 155-174, 2011.

NOGUEIRA, M.; MENDONÇA, E. C. "Feiras e comidas: espaço e tempo em movimento". In: LONDRES, C.; et al. Celebrações e saberes da cultura popular: pesquisa, inventário, crítica, perspectivas. Rio de Janeiro: IPHAN, 2004.

POLLAK, M. "Memória e identidade social". Tradução de Monique Augras. Estudos Históricos. V. 5, n. 10. Rio de Janeiro, p. 200-212, 1992.

SANTOS. J. J. F.; RODRIGUES, C. I. "A feira e os vendedores de CDs e DVDs "piratas"”. Revista Composição. Ano 7, n. 12. Mato Grosso do Sul, p. 8-22, 2013.

SANTOS, M. S. D. "História e Memória: o caso do Ferrugem”. Revista Brasileira de História. v. 23, n. 46. São Paulo, p. 271-295, 2003

SATO, L. "Processos cotidianos de organização do trabalho na feira livre". Revista Psicologia e Sociedade. Edição Especial 1, n. 19, p. 95-102, 2007. 
; SOUZA, M. P. R. "Contribuindo para desvelar a complexidade do cotidiano através da pesquisa etnográfica em Psicologia”. Psicologia USP, São Paulo, v. 12, n.2, 2001. Disponível em: <http://www.scielo.br/scielo.php?script=sci_arttext\&pid=S0103-65642001000200003> Acesso em: 28 out. 2013.

SEVERINO, A. J. Metodologia do trabalho científico. São Paulo: Cortez, 2007.

SILVA, E. V. D. "Turismo comunitário e a potencialização da identidade, da memória e do patrimônio cultural". In: SEABRA, G (Org.). Comunidades, natureza e cultura no turismo. João Pessoa: Editora Universitária da UFPB, 2012, p. 780-788.

SILVA, M. G. D. "Porto da palha: percepções e imagens estruturantes de narrativas sobre (in)sustentabilidade local”. In: Seminário Internacional - Amazônia e Fronteiras do Conhecimento. (NAEA - Núcleo de Altos Estudos Amazônicos). Belém. 2008. Anais... Belém, 2008. Disponível em: <http://www.ufpa.br/naea/siteNaea35/anais/html/geraCapa/FINAL/GT5129-1133-20081128212727.pdf>. Acesso em: 28 de out. 2013.

SILVA, M. R.; COSTA, L. T. T. D. "Como ser paraense desse jeito?: farinha de mandioca e a representação da identidade cultural paraense através das mídias sociais”. In: II CONINTER Congresso Internacional Interdisciplinar em Sociais e Humanidades, Belo Horizonte, 2013. Anais..., Belo Horizonte, p. 1-9, 2013.

TOMAZI, N. D. Sociologia para o ensino médio. São Paulo: Atual, 2007.

WEHLING, A.; WEHLING, M. J. "As estratégias de memória social". Brasilis: Revista de História Sem Fronteiras. Ano 1, n. 1. Rio de Janeiro: Editora Atlântida, 2003.

Recebido em: 30/09/2014 Aprovado em: 15/11/2014 